\title{
Characterization of Tobacco mosaic virus Isolated from Potato Showing Yellow Leaf Mosaic and Stunting Symptoms in Korea
}

\author{
H. W. Jung and W. S. Yun, School of Agricultural Biotechnology and Research Center for New Biomaterials in \\ Agriculture, Seoul National University, Suwon 441-744, Korea; Y. I. Hahm, Alpine Agriculture Experiment Sta- \\ tion, Pyungchang, Kangwon 232-955, Korea; and K.-H. Kim, School of Agricultural Biotechnology and Research \\ Center for New Biomaterials in Agriculture, Seoul National University, Suwon 441-744, Korea
}

\begin{abstract}
Jung, H. W., Yun, W. S., Hahm, Y. I., and Kim, K.-H. 2002. Characterization of Tobacco mosaic virus isolated from potato showing yellow leaf mosaic and stunting symptoms in Korea. Plant Dis. $86: 112-117$.

Four isolates of Tobacco mosaic virus (TMV-potato 1 to 4) were obtained from potato plants (Solanum tuberosum) in cultivated potato plantings in Korea. These isolates were differentiated based on biological properties, symptomatology, and nucleotide sequence analysis of the coat protein $(\mathrm{CP})$ gene. TMV potato isolates caused typical symptoms on 20 inoculated plant species as compared to the type (U1) TMV strain. The four isolates each produced distinctly different symptoms on Gomphrena globosa. In contrast to the type strain of TMV, infections with two of the isolates reported here were not restricted to inoculated leaves of G. globosa but moved systemically through the plants. In addition, three additional systemic hosts (Chenopodium amaranticolor, $C$. quinoa, and C. murale) for TMV were revealed. Sequence analysis of the CP gene differentiated TMV-potato isolates. The CP gene sequence exhibited significant identity (83.1 to $99.2 \%$ ) among TMV-potato isolates while showing 88.1 to $99.4 \%$ identities on predicted amino acid sequences. Based on a comparison of the CP gene nucleotide and deduced amino acid sequences between TMV-potato isolates and other TMV strains, TMV-potato 1, 3, and 4 were closely related to TMV strains U1, U2, V-FAVA, and NC82 with 98.8 to $100 \%$ identity. In contrast, TMV-potato 2 was closely related to TMV strains L, KP, KO-TOB, K1, and K2 with 93.8 to $98.8 \%$ identity.
\end{abstract}

The potato (Solanum tuberosum L. and other tuber-producing species of Solanum), a species native to the high Andean region of South America (9), was introduced to Korea early in the nineteenth century, where it has become an important crop species. Potatoes were grown on about 36,500 ha in 1999 , and their importance is growing with increasing consumption of processed potato chips and French fries in recent years (28). The effects of viruses on potato have been observed since the crop was first brought to Europe in the seventeenth century (9). Leaf rolling and crinkling were associated with low tuber yields and caused by continuous vegetative propagation of the species (37). Because of their economic importance, potato viruses were among the first viruses to be recognized (40).

Although Tobacco mosaic virus (TMV) is distributed worldwide in many crops, it is not common and does not cause an economic problem in potato $(3,23,37)$. TMV is known to infect potato by artificial inocu-

Corresponding author: K.-H. Kim
E-mail: kookkim@snu.ac.kr

Accepted for publication 8 October 2001.

Publication no. D-2001-1130-02R

(C) 2002 The American Phytopathological Society lation and to induce symptoms $(13,16,17)$. Blodgett (3) stated that TMV induced different symptoms on different potato varieties. He also reported that tubertransmission of TMV caused extreme dwarfing and leaf dropping in the next potato generation. Since then, TMV infection in potatoes has been reported in China, India, Hungary (16,23), the Peruvian Andes (36), and Saudi Arabia (1), where it caused symptoms such as bright mosaic, interveinal yellowing, rigid leaves, mild mottling, and severe stunting (37). Although TMV is distributed throughout Korea and is considered to be an important virus in other Solanaceous crops including tomato, pepper, and tobacco $(4,5,25,26,30$, $32,35,44)$, it has not been reported to infect potato in Korea.

TMV, the type member of the Tobamovirus genus, is a rigid, rod-shaped virus $300 \times 18 \mathrm{~nm}$ in size, containing a single-stranded, plus-sense RNA of $6.4 \mathrm{~kb}$ in length (45). TMV is transmitted by mechanical inoculation, grafting, contact between plants, and seed, but not by pollen or through a vector (15). During surveys of viral diseases conducted in Korea, potato plants grown with buckwheat plants on commercial farms were observed to exhibit a yellow leaf mosaic symptom and light stunting. Although the primary causative agent was identified as Potato virus $X$ (PVX) (21), some plants were also infected with an unidentified rigid, rod-shaped virus. We also obtained several other rigid, rod-shaped isolates causing light stunting, deformation, and mosaic from other potato-growing areas in Korea. Here, we report the isolation and characterization of new isolates of TMV from potato plants in Korea referred to as TMV-potato isolates. We also report the cloning and sequencing of the coat protein (CP) genes of these viruses and comparisons to published sequences of other TMV strains. To our knowledge, this is the first report of TMV as a minor disease of potato in Korea and the first sequence report of the natural potato isolate of TMV.

\section{MATERIALS AND METHODS}

Virus source and purification. Leaf samples of potato (S. tuberosum) showing yellow leaf mosaic symptoms and light stunting grown in commercial fields in Korea were examined for virus particles using electron microscopy (EM). Samples containing rigid, long rod-shaped virus particles were homogenized in $0.1 \mathrm{M}$ potassium phosphate. The sap was used to mechanically inoculate Chenopodium amaranticolor, Gomphrena globosa, Datura stramonium, Nicotiana glutinosa, and Tetragonia expansa plants to isolate pure TMV cultures from possible double infections. Virus isolates were inoculated to local lesion hosts and reisolated from local lesions at least three times in succession. Several local lesions were collected at 7 to 14 days postinoculation, and virus particles were observed using EM.

The virus was purified according to the method described by Gooding and Hebert (12). Virus preparations were further purified through sucrose step gradients (10 to $40 \%$ sucrose) and centrifuged at 28,000 $\mathrm{rpm}$ for $2 \mathrm{~h}$. The opalescent viral band was collected and precipitated at 30,000 rpm for $2 \mathrm{~h}$. The viral pellet was then resuspended in $0.01 \mathrm{M}$ phosphate buffer $(\mathrm{pH}$ 7.8). Virus concentrations were estimated spectrophotometrically using an extinction coefficient of $1.325(\mathrm{mg} / \mathrm{ml})^{-1} \mathrm{~cm}^{-1}$ at $A_{260}$ for TMV (45).

Host range. To test host ranges and symptom development, purified viruses were mechanically inoculated into Capsicum annuum, Chenopodium amaranticolor, C. murale, C. quinoa, Cucumis sativus, D. stramonium, G. globosa, Lycoper- 
sicon esculentum, Nicotiana benthamiana, $N$. clevelandii, $N$. debneyi, $N$. glutinosa, $N$. rustica, N. tabacum cv. Samsun nn, N. tabacum cv. Xanth-nc, N. sylvestris, Physalis floridana, Pisum sativum, $S$. tuberosum cv. Superior, and T. expansa predusted with Carborundum. Symptoms produced on each test plant were compared with two standard isolates of TMV, i.e., TMV-U1 (TMV-common strain) from American Type Culture Collection (ATCC, Manassas, VA) and TMV-KP (Korean pepper isolate) from J. K. Choi (Kangwon National University). The experiment was conducted three times using at least three plants for each inoculation. These plants were maintained in the glasshouse at 20 to $25^{\circ} \mathrm{C}$ and observed for symptom development for 4 weeks.

Antiserum production. Antisera against purified virus particles (TMV-potato 1 and 2) were produced as described by Salazar (37) and van Regenmortel (43). Titers of the two antisera were $1 / 1,024$ to $1 / 2,048$ when determined by enzyme-linked immunosorbent assay (ELISA) using sonicated virus. There were no nonspecific reactions. These antisera were used for Western blotting and ELISA.

Electron microscopy. Formvar-coated grids were floated for 1 min on drops of purified virus preparations and crude sap extracted from infected leaf tissues of host plants. Grids were washed with distilled water and stained with $2 \%$ sodium phosphotungstate for $1 \mathrm{~min}$ and examined for virus in an EM (Hitachi-7100, Hitachi, Tokyo, Japan). Particle length was measured on $\times 30,000$ enlarged photographs, and the normal length was calculated from the measurements of 100 particles. Ultrathin leaf sections of Chenopodium amaranticolor and $G$. globosa showing distinct symptoms were selected and prepared according to a procedure described by Kitajima et al. (24).

Protein and RNA analyses. For protein analysis, inoculated and systemic upper leaf tissues were ground and resuspended in $30 \mu \mathrm{l}$ of Laemmli loading buffer (27) at 2 to 4 weeks after inoculation. Proteins extracted from healthy plants and purified virus were used as negative and positive controls, respectively. The relative molecular mass of TMV-potato isolate $\mathrm{CP}$ was determined by $12.5 \%$ sodium dodecyl sulfate-polyacrylamide gel electrophoresis of purified virus preparation (27). Following electrophoresis, the polypeptide bands were stained with Coomassie brilliant blue and destained (38). The protein was analyzed on Western blots using antiserum prepared against TMV-potato 1, and products were visualized using a Biotin/StreptAvidin kit (Amersham Pharmacia Biotech, Buckinghamshire, England). All antisera were preincubated with healthy plant sap to remove antibodies that reacted with plant antigens before use. ELISA was performed as described by Clark and Ad- ams (8). Immunoglobulins were purified from antisera to TMV-potato 1 and 2 using a protein-A cellulose column (Sigma, Saint Louis, MO) and conjugated with alkaline phosphatase (8).

RNA was extracted from purified virus particles and inoculated to plants using Trizol reagent following manufacturer's instructions (Life Technologies, Gaithersburg, MD). The size and quality of the RNAs were determined by electrophoresis in $1 \%$ denaturing agarose gel containing formaldehyde using molecular mass size marker (1-kb ladder; BioRad, Hercules, CA).

Reverse transcription-polymerase chain reaction (RT-PCR) and sequence analysis. RT-PCR was performed as described previously $(20,21)$ using TMV $5 \mathrm{pr}$ (5'-GTTTTAAATATGTCTTACAG-3') and TMV 3pr (5'-TGAGGTAGTCAAGAT GCATA-3') complementary to nucleotides 5703-5722 and 6208-6189, respectively, of TMV China strain (GenBank Accession Nos. NC-001367 and AF165190) (34). Infection by PVX, Potato virus Y (PVY), Alfalfa mosaic virus (AlMV), Potato leaf roll virus (PLRV), or Potato virus S (PVS) was confirmed using previously described oligonucleotide primer sets that specifically bind to each virus $(7,20-22)$. PCR conditions were as follows: $94^{\circ} \mathrm{C}, 1 \mathrm{~min}(1$ cycle) and 35 cycles of $94^{\circ} \mathrm{C}, 30 \mathrm{~s} ; 54^{\circ} \mathrm{C}$, $30 \mathrm{~s} ; 72^{\circ} \mathrm{C}, 45 \mathrm{~s}$ followed by one cycle of elongation at $72^{\circ} \mathrm{C}$ for $10 \mathrm{~min}$. The amplified DNA fragments were ligated into TOPO vector and transformed into Escherichia coli 10F (Invitrogen, Carlsbad, CA). Recombinant plasmids containing cDNA inserts of the correct sizes (480 bp for TMV CP gene) were sequenced by the dideoxynucleotide chain termination method using the ABI Prism Terminator Cycle Sequencing Ready Reaction Kit and the ABI Prism 377 genetic analyzer (Perkin Elmer, Foster City, CA) located at the National Instrumentation Center for Environmental Management (CALS, SNU) according to the manufacture's instructions. All clones were sequenced in both orientations, and at least three different DNA clones representing each isolate were sequenced. TMV-related sequences were initially identified using the BLAST search program of GenBank (2). Phylogenetic analysis was performed to determine the relationship of TMV with other TMV strains using the ClustalW algorithm of LaserGene program (DNASTAR, Madison, WI).

\section{RESULTS}

Identification and incidence of TMV isolates in potato. Initially, TMV-potato isolates were detected in potato plants exhibiting unusual yellow leaf mosaic symptoms and stunting in the Bongpyung area in Korea. Based on EM observation and ELISA, these plants were frequently found to be infected with both PVX and TMV. TMV also was detected in glasshouse and field potato plants in other areas showing severe leaf mosaic and stem necrosis. From these, 17 potato plants of five different commercial cultivars (cv. Atlantic, Dejima, Irish Cobbler, Jopoong, and Superior) grown in different locations in the Kangwon area in Korea tested positive for TMV using ELISA. Of the 17 potato plants, 7, 5, and 3 were from cultivars Superior, Atlantic, and Jopoong, respectively. Seven isolates of TMV, each from a

Table 1. Homology of the predicated amino acid sequences of Tobacco mosaic virus (TMV)-potato isolates and corresponding regions of other TMV strains

\begin{tabular}{lcccc}
\hline & \multicolumn{4}{c}{ Percent identity } \\
\cline { 2 - 5 } Strains & Potato 1 & Potato 2 & Potato 3 & Potato 4 \\
\hline Potato 1 & - & 83.1 & $97.5-98.8$ & 98.1 \\
NC82 & 99.4 & 83.1 & $97.5-98.8$ & 98.1 \\
V-FAVA & 99.4 & 83.1 & $97.5-98.8$ & 98.1 \\
U1 & 99.4 & 83.1 & $97.5-98.8$ & 98.1 \\
U2 & 99.4 & 83.1 & $97.5-98.8$ & 98.1 \\
Potato 4 & 98.1 & 81.9 & $96.2-97.5$ & - \\
Potato 3 & $97.5-98.8$ & $82.5-83.8$ & - & $96.2-97.5$ \\
RAKKYO & 95.6 & 80.6 & $93.8-95.0$ & 94.4 \\
INDIA & 93.8 & 78.1 & $91.9-93.1$ & 92.5 \\
L & 83.1 & 98.1 & $82.5-83.8$ & 81.9 \\
KO-TOB & 83.1 & 98.1 & $82.5-83.8$ & 81.9 \\
PEPPER & 81.9 & 96.9 & $81.2-82.5$ & 80.6 \\
K1 & 80.6 & 96.2 & $80.0-81.2$ & 79.4 \\
K2 & 80.6 & 95.6 & $80.0-81.2$ & $86.3-79.4$ \\
Potato 2 & 83.1 & - & $82.5-83.8$ & 81.9 \\
O & 69.8 & 72.3 & $68.6-69.8$ & 69.8 \\
ORSV & 67.9 & 70.4 & $67.3-67.9$ & 67.9 \\
P & 71.5 & 73.4 & $70.3-71.5$ & 70.9 \\
OB & 58.8 & 58.8 & $57.5-58.8$ & 58.1 \\
TMGMV & 70.6 & 70.6 & $69.4-70.6$ & 70.0 \\
CRUCIFER & 44.9 & 48.1 & $44.3-44.9$ & 44.9 \\
COWPEA & 40.6 & 39.4 & $40.0-40.6$ & 40.0 \\
CGMMV & 36.9 & 36.2 & 36.2 & 36.9 \\
\hline
\end{tabular}

${ }^{a}$ Four isolates were grouped into TMV-potato 3 based on symptom developments in different host plants. 
different potato plant, were selected for further characterization.

Antisera to TMV potato were employed in the ELISA to determine the incidence of natural TMV infection in potato fields. Among 50 potato samples showing yellow leaf mosaic and light stunting that were collected from the Kangwon area, five were positive for TMV, including four for both TMV and PVY and one for TMV and PVX. The other symptomatic samples were positive for other potato viruses. Twenty-nine were infected with PVY and six were infected with PVX, including five

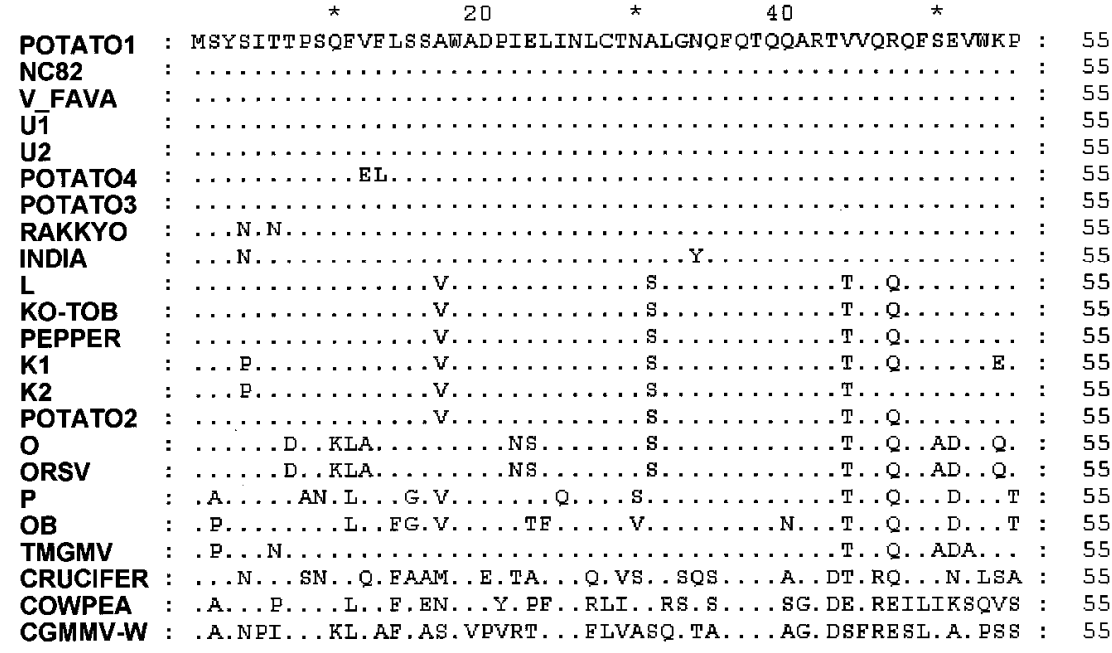

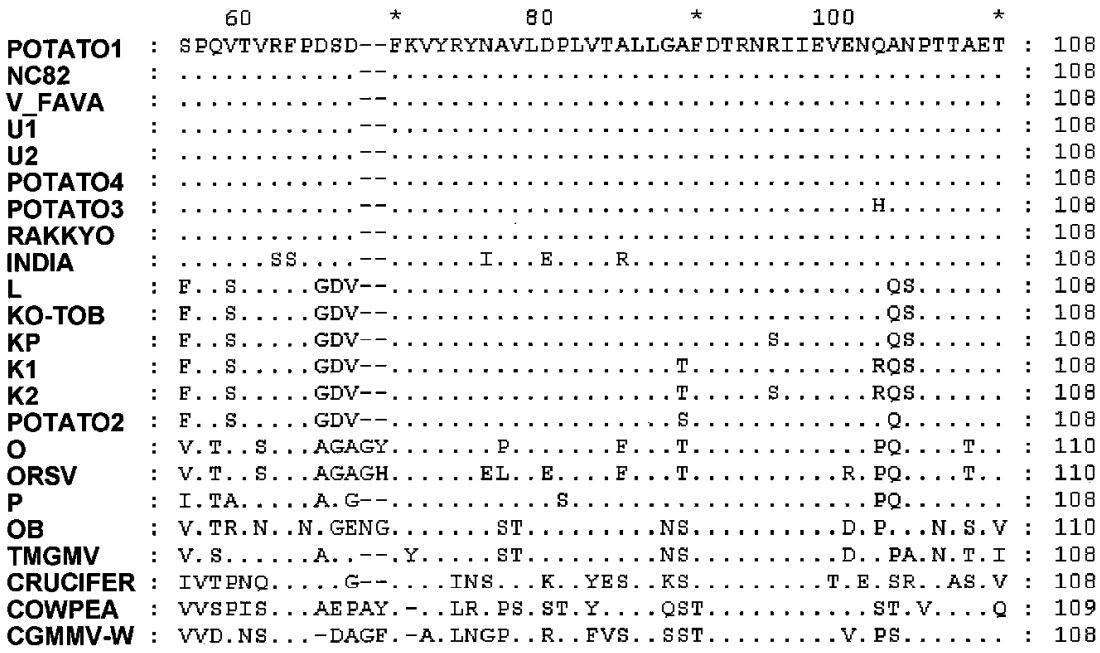

$$
120 * 140 * 160
$$

\begin{tabular}{|c|c|c|c|}
\hline & & 20 & \\
\hline & & $\ldots \ldots \ldots \ldots \ldots \ldots \ldots \ldots \ldots \ldots \ldots \ldots \ldots \ldots \ldots \ldots \ldots$ & \\
\hline & & 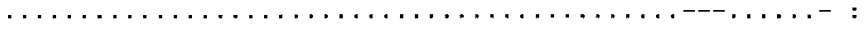 & \\
\hline & & 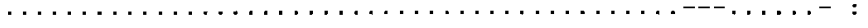 & \\
\hline & & 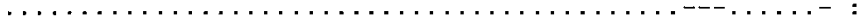 & \\
\hline & & 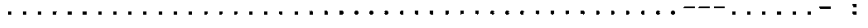 & \\
\hline & & 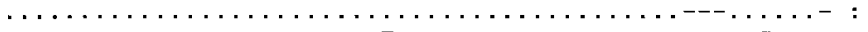 & \\
\hline & & $\ldots \ldots \ldots \ldots \ldots \ldots \ldots \ldots \ldots \ldots \ldots \ldots,{ }^{--}$ & \\
\hline & & $\ldots \ldots \ldots \ldots \ldots \ldots \ldots \ldots \ldots \ldots \ldots \ldots \ldots \ldots \ldots \ldots$ & \\
\hline & & $\ldots$ N. . . . . I. QN . . .M. . . - . . A. . - & \\
\hline & & . . L L . QN . . .M. . . .-- . A. . - & \\
\hline & & $\ldots$. L . QN . . .M. . . . --- . AA . . - & \\
\hline & & . M. ...-- . A. & \\
\hline & & . . . . . . . . I. . QN . . & \\
\hline & & 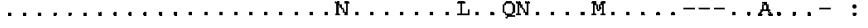 & \\
\hline & & 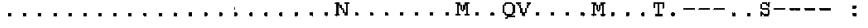 & \\
\hline & & $\ldots \ldots \ldots \ldots$ N. . . N.M. QV . . M. . T. - . . S- & \\
\hline & & . . . . . AS. S. .N. . . . M. QAL . A. . T. -- A. T. & \\
\hline & & . . . MM.TA. . .V.N.T.-- . TT & \\
\hline & & .M. . QAG. . & \\
\hline & & $\mathrm{VL}--. \mathrm{P}$ & \\
\hline & & $\ldots \mathrm{V} . \mathrm{T}$ & \\
\hline & & . T. A. AE. & \\
\hline
\end{tabular}

Fig. 1. Alignment of predicted amino acid sequence of coat protein (CP) genes of four Tobacco mosaic virus (TMV)-potato isolates and other TMV strains. The amino acids are represented by single letter amino acid codes. Alignment was generated using the program ClustalW (DNASTAR). Asterisks denote the tenth position from the previously numbered amino acids. samples that were positive for both PVX and PVY. Ten samples were positive for PLRV. PVS and AlMV were not detected in any samples. From 1999 to 2000, natural incidence of potato plants that showed yellow leaf mosaic and light stunting was varied ( 0 to $40 \%)$ depending on potato cultivars and locations where they were grown. For example, PLRV was frequently found in cv. Superior (as high as $30 \%$ natural incidence), while up to $40 \%$ of potato cv. Atlantic was infected by PVY.

RT-PCR and sequence analysis. Oligonucleotide primers (TMV 5pr and 3pr) specific for the TMV CP gene were used in RT-PCR, and a single DNA fragment of the expected size was obtained using total RNA extracted from purified viruses and G. globosa infected with TMV-potato isolates (potato 1 to 4 ). At least three cDNA clones of the $\mathrm{CP}$ gene of each potato isolate were selected and sequenced. The 480 nucleotide sequences of the entire $\mathrm{CP}$ gene of TMV-potato 1 to 4 were obtained and deposited into GenBank (accession numbers AF260730 for potato 1; AF318214 for potato 2; AF318213, AF318215, AF318216, and AF318217 for potato 3; AF318218 for potato 4). Computer-aided comparison of the $\mathrm{CP}$ gene sequences of TMV-potato isolates with one another and with other tobamoviruses confirmed each isolated was a TMV $(10,31)$.

The $\mathrm{CP}$ gene sequences exhibited a range of significant identity (71.5 to 99.2\%) among the TMV-potato isolates (data not shown). TMV-potato 1, 3, and 4 were closely related with a range of 97.7 to 99.2\% nucleotide sequence identity and with 97.5 to $98.8 \%$ deduced amino acid sequence identity (Table 1). TMV-potato 2 was more distantly related to the other potato isolates with 70.0 to $71.5 \%$ nucleotide sequence identity and 81.9 to $83.8 \%$ in predicted amino acid sequences of the $\mathrm{CP}$ gene (Table 1). TMV-potato 1, 3, and 4 have few amino acid substitutions in the $\mathrm{CP}$, but potato 2 has many different nucleotide residues and up to 19 different amino acid residues in this region (Fig. 1).

Based on CP amino acid sequence homology, TMV-potato 1 was found to be closely related to TMV strains NC82, VFAVA, U1, and U2 strains (Table 1 and Fig. 2). TMV-potato 2 was closely related to TMV strains $\mathrm{L}(98.1 \%)$, KO-TOB (98.1\%), KP (96.9\%), K1 (96.2\%), and K2 $(95.6 \%)$. Potato 3 and 4 were related to TMV-potato 1 group with 97.5 to $98.8 \%$ amino acid identities (Table 1).

Host range and symptomatology. The seven TMV isolates were regrouped into four different isolates (TMV-potato 1 to 4) based on differences in symptoms on host plants and in nucleotide sequences of their $\mathrm{CP}$ genes. The TMV-potato isolates were mechanically transmissible to most plants of the host range tested except Leguminosae species, as determined by symptomatology and RT-PCR 28 days after mechani- 
cal inoculation (Table 2). Chenopodium amaranticolor, C. quinoa, and C. murale developed chlorotic and/or necrotic local lesions on inoculated leaves (Table 2). Although infection by known strains of TMV, including TMV-U1, is restricted to inoculated leaves of Chenopodiaceae plant species and G. globosa (35), the TMV-KP, TMV-potato 2, and TMV-potato 3 systemically infected all of these species (Table 2). Each TMV potato isolate produced distinct symptoms on $G$. globosa, i.e., necrotic local lesions with reddish boundaries only on inoculated leaves (potato 1), systemic

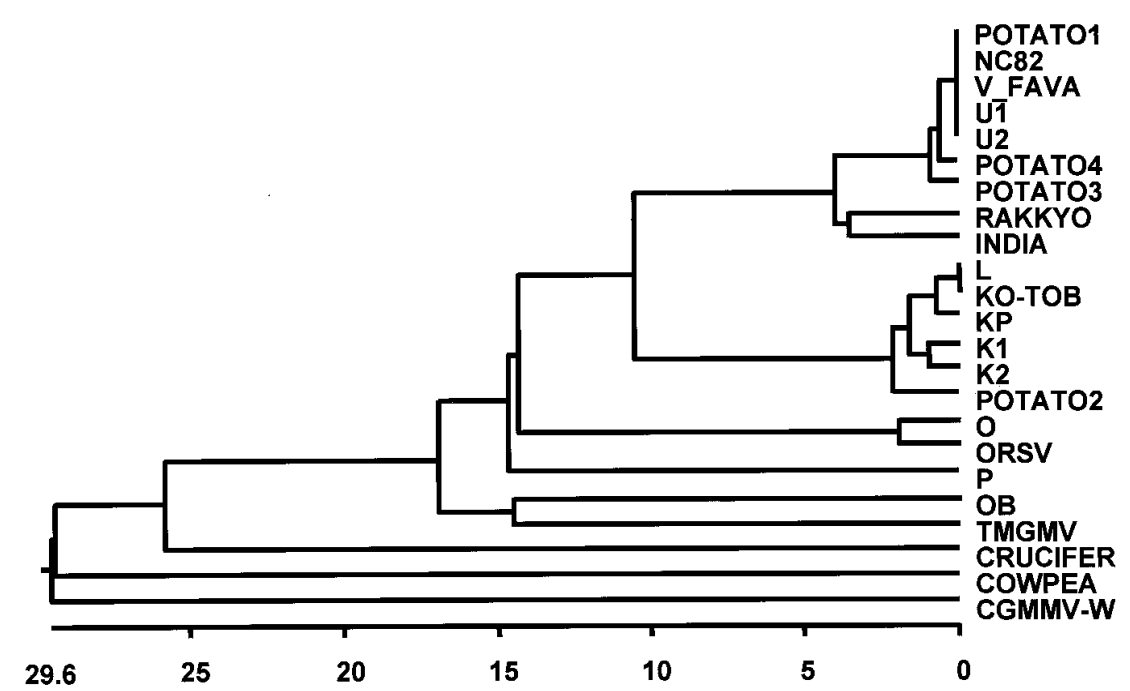

Fig. 2. Phylogenetic tree constructed from predicted amino acid sequence alignment of coat protein (CP) genes of four Tobacco mosaic virus (TMV)-potato isolates and other TMV strains. The dendrogram was generated by using the ClustalW method (DNASTAR). The sources of sequence data were from the following GenBank accession numbers: NC82 (X68110) V-FAVA (AJ011933), U1 (M34077), U2 (M22483), RAKKYO (D63809), INDIA (AF126505), L (X02144), KO-TOB (AF103780), KP (L35073), K1 (AJ243571), K2 (Z92909), O (AF141927), ORSV (U34586), P (D13367), OB (L11665), TMGMV (AF132908), CRUCIFER (Z29370), COWPEA (J02413), and CGMMV-W (V01551). The line below the tree represents the percent divergence. mosaic symptom (potato 2), systemic necrotic lesions (potato 3 ), and a symptomless infection (potato 4). Accumulation of each TMV-potato isolate on both inoculated and systemic leaves of G. globosa was confirmed using RT-PCR and Western analyses (Fig. 3A and B). Although the TMV potato 4 produced no visible systemic symptoms on this host, replication in inoculated leaves was observed (Table 2 and Fig. 3A and B).

Symptoms induced by these TMVpotato isolates on different test plants are summarized in Table 2. All four TMVpotato isolates produced necrotic local lesions on inoculated leaves of $N$. glutinosa, $N$. rustica, $N$. sylvestris, $N$. tabacum cv. Xanthi nc, and T. expansa. TMV-potato 2 and 3 caused severe systemic symptoms on $C$. annuum, $N$. benthamiana, $N$. clevelandii, and $N$. debneyi, while potato 1 and 4 caused no distinct symptoms on inoculated leaves of $N$. benthamiana and $N$. clevelandii. TMV-potato 1 and 4 caused similar symptoms on inoculated test plants, while TMV-potato 4 expressed less severe symptoms. TMV-potato 2 produced more severe systemic symptoms on several test plants, such as $C$. annuum and $N$. debneyi, than did other TMV-potato isolates. Although the TMV-potato isolates produced no visible systemic symptoms on tomato (L. esculentum), infection was confirmed by using RT-PCR (Fig. 3C), and typical symptoms resulted when extracts were inoculated onto other indicator plants (data

Table 2. Symptom development on indicator plant species by inoculation with purified Tobacco mosaic virus (TMV)-potato strains in Korea

\begin{tabular}{|c|c|c|c|c|c|c|}
\hline \multirow[b]{2}{*}{ Plant species } & \multicolumn{6}{|c|}{ Leaf symptoms ${ }^{\text {a }}$ caused by TMV-potato strains } \\
\hline & $\mathbf{U} 1^{\mathbf{b}}$ & KP' & Potato 1 & Potato 2 & Potato 3 & Potato 4 \\
\hline \multicolumn{7}{|l|}{ Amaranthaceae } \\
\hline Gomphrena globosa & NL/- & NL/M & NL/- & NL/SM & NL/NRL & SL/- \\
\hline \multicolumn{7}{|l|}{ Chenopodiaceae } \\
\hline Chenopodium amaranticolor & NL/- & NL/Cur, Dist & NL/- & NL/Cur, Dist & NL/Cur, Dist & NL/- \\
\hline C. quinoa & $\mathrm{CL} /-$ & CL/Cur, VN & $\mathrm{CL} /-$ & CL/Dist, VN & CL/Dist, VN & CL/- \\
\hline \multirow{2}{*}{\multicolumn{7}{|c|}{$\begin{array}{l}\text { C. murate } \\
\text { Cucurbitaceae }\end{array}$}} \\
\hline & & & & & & \\
\hline Cucumis sativus & $-1-$ & $-1-$ & $-1-$ & $-1-$ & $-1-$ & $-1-$ \\
\hline \multicolumn{7}{|l|}{ Solanaceae } \\
\hline Capsicum аппиит & NL/M & NL/SM & NL/M & VN/M, SN & NL/M & NL/M \\
\hline Datura stramonium & NS/- & NS/- & $\mathrm{NS} /-$ & NS/- & $\mathrm{NS} /-$ & NS/- \\
\hline Lycopersicon esculentum & NL/SL & NL/SL & NL/SL & NL/SL & NL/SL & NL/SL \\
\hline Nicotiana benthamiana & SL/MM & SN/M, SN & SL/MM & SN/M, SN & SN/M, SN & SL/MM \\
\hline N. clevelandii & SL/M, Mot & VN/M, Mot & SL/M, Mot & VN/M, Mot, VN & VN/M, Mot & SL/M, Mot \\
\hline N. debneyi & NL/M, Mot & NL/M, Mot & NL/M, Mot & NL, SN/M, VN & NL/M, Mot & NL/M \\
\hline N. glutinosa & NL/- & NL/- & NL/- & NL/- & NL/- & $\mathrm{NL} /-$ \\
\hline N. sylvestris & $\mathrm{NL} /-$ & $\mathrm{NL} /-$ & $\mathrm{NL} /-$ & NL/- & NL/- & $\mathrm{NL} /-$ \\
\hline N. rustica & NL/- & NL/- & NL/- & NL/- & NL/- & NL/- \\
\hline N. tabacum cv. Samsun nn & NL/M & NL/M & NL/M & NL/M & NL/M & NL/M \\
\hline N. tabacum cv. Xanthi nc & NL/- & $\mathrm{NL} /-$ & $\mathrm{NL} /-$ & NL/- & $\mathrm{NL} /-$ & $\mathrm{NL} /-$ \\
\hline Solanum tuberosum cv. Superior & NL/SL & NL/NL & NL/SL & NL/NL & NL/SL & NL/SL \\
\hline Physalis floridana & $\mathrm{M} / \mathrm{M}$ & $\mathrm{M} / \mathrm{M}$ & $\mathrm{M} / \mathrm{M}$ & $\mathrm{M} / \mathrm{M}$ & $\mathrm{M} / \mathrm{M}$ & $\mathrm{M} / \mathrm{M}$ \\
\hline Tetragonia expansa & NL/- & NL/- & NL/- & NL/- & NL/- & NL/- \\
\hline \multicolumn{7}{|l|}{ Leguminosae } \\
\hline Pisum sativum & $-1-$ & $-1-$ & $-1-$ & $-1-$ & $-1-$ & $-1-$ \\
\hline
\end{tabular}

a Symptoms on inoculated leaves/upper leaves induced by TMV strains. CL, chlorotic local lesions; CS, chlorotic spots; Cur, leaf curling; Dist, leaf distortion; M, mosaic; Mot, mottle; NS, necrotic spots; NL, necrotic local lesions; NRL, necrotic ring local lesions; MM, mild mosaic; SM, severe mosaic; SN, stem necrosis; VN, vein necrosis; -, no infection. SL, symptomless (typical symptoms not produced but the virus was detected by electron microscopy or reverse transcription-polymerase chain reaction).

b TMV-U1 from TMV common strain from American Type Culture Collection.

${ }^{c}$ TMV-KP (Korean pepper isolate) kindly donated by J. K. Choi at Kangwon National University, Korea. 
not shown). This study also revealed additional systemic hosts for TMV (potato 2 and 3) such as C. amaranticolor, C. quinoa, $C$. murale, and G. globosa, which have not been reported previously to be systemic hosts for TMV.

TMV-potato 1, 3, and 4 caused necrotic lesions on inoculated leaves of potato $\mathrm{cv}$. Superior, whereas TMV-potato 2 caused systemic necrotic symptoms similar to those described previously for TMV (13). Systemic infection of potato by all TMVpotato isolates was revealed by RT-PCR (Fig. 3E). Symptoms of TMV-potato 1 and 4 were similar to those of TMV-U1. Symptoms of TMV-potato 2 and 3 were similar to those of TMV-KP strain, but TMVpotato 3 caused less severe symptoms (Table 2).

\section{DISCUSSION}

Our results show that native field potatoes were infected by TMV in Korea. Diseased potato plants were first observed in commercial farms in the Bongpyung area in Korea in 1999 (TMV-potato 2). In this region, potatoes are often cultivated in the same area with buckwheat. Typical TMV symptoms were observed in both potato and buckwheat plants during the 2000 growing season. Since the $\mathrm{CP}$ nucleotide sequence of a TMV isolated from buckwheat was $100 \%$ identical to that of TMVpotato 2 (unpublished data), the TMVpotato 2 may come from buckwheat. TMV infection in the potato field may increase if farmers use harvested potatoes as seed potato in subsequent years. Similarly, the $\mathrm{CP}$ gene nucleotide sequences of the TMVpotato 1,3 , and 4 were very similar to those of the CP genes of other TMVs re- ported in other crops in Korea, including TMVs isolated from pepper, tomato, and tobacco plants $(25,29)$. Comparison of the $\mathrm{CP}$ amino acid sequences deduced from the nucleotide sequences of the four isolates and other reference strains of TMV revealed several amino acid variations and nonconservative alterations that were found exclusively in CPs of the four TMV potato isolates. Because potato plants are frequently cultivated with pepper, tomato, or tobacco, these crops may serve as the source for TMV infection in potato (35). However, this relationship has yet to be confirmed.

The TMV-potato isolates described in this paper were similar to the TMV-U1 strain in particle length and morphology, apparent molecular mass of the $\mathrm{CP}$, and nucleotide and predicted amino acid sequences of CP gene. Although we did not sequence the whole genome, it has previously been shown that comparison of the $\mathrm{CP}$ gene sequence reveals a similar relationship among TMV strains as do comparisons of longer sequences $(11,33,41)$.

To date, TMV has been detected frequently in potato cultivars, i.e., Dejima, Superior, and Jopoong, but was infrequent in other potato cultivars such as Atlantic and Irish Cobbler. The TMV isolate produced necrotic spots on inoculated leaves in the potato $\mathrm{cv}$. Superior, which gradually became necrotic and caused systemic infections. It remains to be determined whether TMV can infect and cause severe damage to other potato cultivars. Although TMV is not considered an economically important potato virus and is not common in potato fields in Korea, we observed TMV infection in several regions. Given
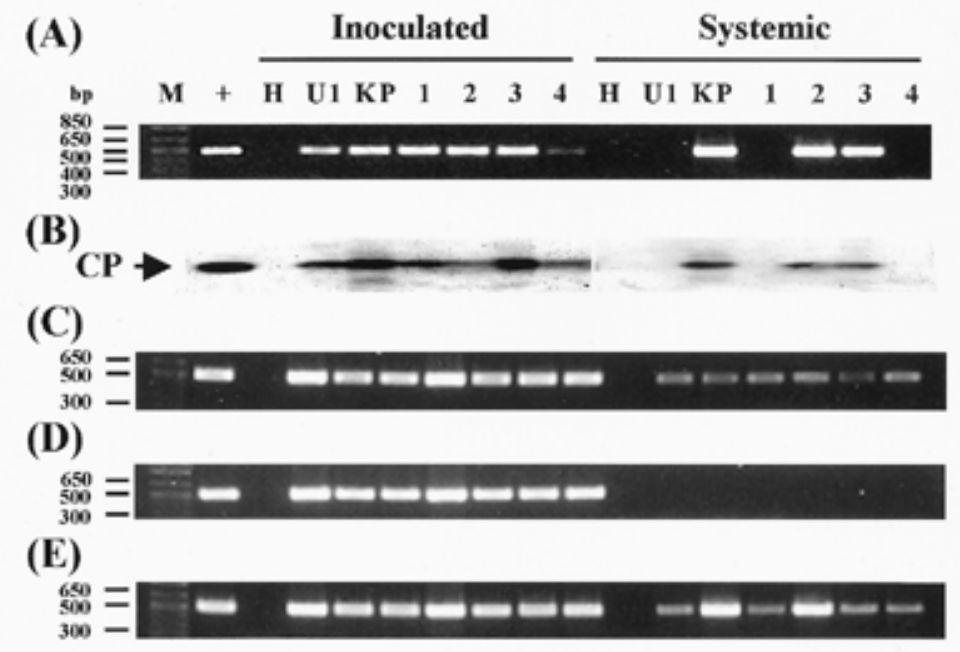

Fig. 3. Replication of Tobacco mosaic virus (TMV)-potato isolates detected by reverse transcriptionpolymerase chain reaction (RT-PCR) (A, C to E) and Western blot (B) analyses. Total RNA A, or protein $\mathbf{B}$, was extracted from inoculated leaves and upper uninoculated systemic leaves of Gomphrena globosa; C, Lycopersicon esculentum; D, Nicotiana tabacum cv. Xanthi nc; and E, Solanum tuberosum $\mathrm{cv}$. Superior with the virus indicated. The + indicates the results obtained using purified TMV RNA (A, C to E) or virus (B). Total RNAs or proteins were extracted at 14 days postinoculation (DPI) (G. globosa and N. tabacum cv. Xanthi nc) or at 28 DPI (L. esculentum and S. tuberosum cv. Superior) and subjected to RT-PCR and/or Western blot analyses. Position of coat protein (CP) is indicated by arrow. the stability of the virus and its high risk of mechanical transmission in the field, TMV has high potential to cause more damage in the potato fields.

TMV strains are numerous and diverse in biological properties. They infect many wild and cultivated plant species, often causing devastating disease (43). Although the four TMV-potato isolates reported here did not show clear differences in symptom development in the potato cultivars tested, they showed clear differences in the symptom development on G. globosa. TMVpotato 2 produced more severe symptoms than other isolates on many tested plants in general. The deduced amino acid sequences of the $\mathrm{CP}$ gene of these isolates revealed that there were many amino acid differences between TMV-potato 2 and the other TMV-potato isolates (Fig. 1). A concern we had in interpreting results from host-range experiments was the possibility that differences in symptom developments on Chenopodium amaranticolor, Cucumis sativus, G. globosa, L. esculentum, S. tuberosum cv. Superior, N. tabacum cv. Xanthi nc, and $P$. sativum by TMV-Potato isolates were controlled simply by the rate of virus spread from the inoculated leaves and environmental conditions. For each inoculation, we closely observed the plants for the appearance of any symptoms for up to 4 weeks in order to detect symptoms caused by slow virus movement and/or replication. Each inoculated plant showing no systemic symptoms was further tested by RT-PCR using extracts from inoculated and noninoculated upper systemic leaves and, depending upon the PCR results, classified as no infection and symptomless infection. TMV-potato isolates showed very slow virus transport into systemic leaves of $S$. tuberosum cv. Superior except for TMV-potato 2 isolate. These differences among TMV-potato isolates may be due to nucleotide sequence changes in each isolate. The virus titer, temperature in the glasshouse, and possible contamination with other viruses was closely examined. The amount of virus used for inoculation was not positively correlated with the symptoms displayed on test plants. No virus infection was observed on Cucumis sativus or $P$. sativum, even though we increased the amount of purified virus inoculum.

The importance of the viral CP in symptom development and in determining host range differences has been shown for Tobamovirus--plant combinations $(6,14)$. Similarly, the role of $\mathrm{CP}$ as host range determinant was also reported for Cucumber mosaic virus (42). Because amino acid changes are present in the $\mathrm{CP}$ of each potato isolate, these changes may be responsible for symptom differences in tested plants. TMV-potato 2 is more closely related to TMV-KP, based on their CP phylogeny, than to the other potato isolates. Their similar symptom developments on 
indicator hosts are in agreement with this observation. Systemic infection, however, requires continuous virus-host interactions in virus replication, cell-to-cell movement, and long-distance movement, and thus is a complex process. Sequences in other regions of the TMV genome have also been shown to be responsible for differences in symptom development. By constructing chimeric viruses or by introducing sitedirected mutations, it was suggested that amino acid changes in the replicase, MP, and nucleotide changes in the noncoding regions are also involved in defining infection phenotype $(6,18,19,39)$. Future experiments will determine if these amino acid substitutions between potato 2 and other isolates are responsible for the symptom differences displayed. Molecular characteristics such as pseudo-recombinants or full-length genomic RNA sequences will also be required in order to define different pathological characteristics among the TMV-potato isolates.

\section{ACKNOWLEDGMENTS}

This work was supported in part by a research grant from the Rural Development Administration to KHK (500-20012008). WSY is grateful for the graduate fellowship provided by the Ministry of Education through the Brain Korea 21 Project.

\section{LITERATURE CITED}

1. Al-Shahwan, I. M., Abdalla, O. A., and AlSaleh, M. A. 1997. Viruses in the northern potato-producing regions of Saudi Arabia. Plant Pathol. 46:91-94.

2. Altschul, S. F., Madden, T. L., Schaffer, A. A., Zhang, J., Zhang, Z., Miller, W., and Lipman, D. J. 1997. Gapped BLAST and PSI-BLAST: A new generation of protein database search programs. Nucleic Acids Res. 25:3389-3402.

3. Blodgett, E. M. 1927. Tobacco mosaic on potatoes. Phytopathology 17:727-734.

4. Broadbent, L. H. 1965. The epidemiology of tomato mosaic. XI. Seed-transmission of TMV. Ann. Appl. Biol. 56:177-205.

5. Cayman, P., and Thompson, G. T. 1990. Characterization of tobamoviruses isolated from tomatoes in South Africa. Phytophylactica 22:265-267.

6. Chen, J., Watanabe, Y., Sako, N., Ohshima, K., and Okada, Y. 1996. Mapping of host range restriction of the Rakkyo strain of Tobacco mosaic virus in Nicotiana tabacum cv. Bright yellow. Virology 226:198-204.

7. Cho, H. S., Jun, S. I., Kwon, S. Y., Park, E. K., Paek, K. Y., and Paek, K.-H. 1994. Isolation and nucleotide sequence analysis of a partial cDNA clone for Potato virus $Y$-VN (Korean isolate) genome. Mol. Cells 4:143148.

8. Clark, M. F., and Adams, A. M. 1977. Characteristics of the microplate method of enzymelinked immunosorbent assay for the detection of plant viruses. J. Gen. Virol. 34:475-483.

9. de Bokx, J. A. 1972. Viruses and seed-potato production. Center for Agricultural Publishing and Documentation, Wageningen, Netherlands.

10. Gibbs, A. J. 1986. Tobamovirus classification. Pages 167-180 in: The Plant Viruses, Vol. 2.
M. H. V. van Regenmortel and H. FraenkelConrat, ed. Plenum Press, New York.

11. Goelet, P., Lomonossoff, G. P., Butler, P. J., Akam, M. E., Gait, M. J., and Karn, J. 1982. Nucleotide sequence of Tobacco mosaic virus RNA. Proc. Natl. Acad. Sci. USA 79:58185822.

12. Gooding, J. G. V., and Hebert, T. T. 1967. A simple technique for purification of Tobacco mosaic virus in large quantities. Phytopathol. Notes 1285.

13. Hansen, H. P. 1960. Tobacco mosaic virus carried in potato tubers. Am. Potato J. 37:95101.

14. Hilf, M. E., and Dawson, W. O. 1993. The tobamovirus capsid protein functions as a host-specific determinant of long-distance movement. Virology 193:106-114.

15. Hollings, M., and Huttinga, H. 1976. Tomato mosaic virus. CMI/AAB Description of Plant Viruses No. 156

16. Horvath, J. 1977. Natural occurrence of a strain of Tomato mosaic virus on potato as in Hungary. Potato Res. 20:347.

17. Horvath, J. A., Horvath, L. M., and Besada, W. H. 1978. Natural occurrence of a strain of Tomato mosaic virus on potato in Hungary. Acta Phytopathol. Acad. Sci. Hung. 13:299305.

18. Ishikawa, M., Kroner, P., Ahlquist, P., and Meshi, T. 1991. Biological activities of hybrid RNAs generated by $3^{\prime}$-end exchanges between tobacco mosaic and brome mosaic viruses. J. Virol. 65:3451-3459.

19. Ishikawa, M., Meshi, T., Watanabe, Y., and Okada, Y. 1988. Replication of chimeric tobacco mosaic viruses which carry heterologous combinations of replicase genes and $3^{\prime}$ noncoding regions. Virology 164:290-293.

20. Jung, H. W., Jung, H. J., Yun, W. S., Kim, H. J., Hahm, Y. I., Kim, K.-H., and Choi, J. K. 2000. Characterization and partial nucleotide sequence analysis of Alfalfa mosaic Alfamovirus isolated from potato and azuki bean in Korea. Plant Pathol. J. 16:269-279.

21. Jung, H. W., Yun, W. S., Seo, H. W., Hahm, Y. I., and Kim, K.-H. 2000. Characterization and partial nucleotide sequence of Potato virus $X$ isolated from potato in Korea. Plant Pathol. J. 16:110-117.

22. Jung, Y. H., Jeon, J. H., Choi, K. H., Kim, H. S., Oh, H. W., and Jung, H. 1997. Detection of Potato virus $S$ using ELISA and RT-PCR technique. Korean J. Plant Pathol. 13:317322.

23. Juretic, N., Horvath, W., Besada, W. H., Horvath, A., and Lonhard, M. 1977. Serological relationships of Tomato mosaic virus isolated from potato to two members of tobamovirus. J. Indian Potato Assoc. 4:46-65.

24. Kitajima, E. W., Camargo, J. B., and Costa, A. S. 1968. Intranuclear crystals and cytoplasmic membranous inclusions associated with infection by two Brazilian strains of Potato virus Y. J. Electron Microscopy 7:219-227.

25. Koh, H. K., Song, E. K., Lee, S. Y., Park, Y. I., and Park, W. M. 1992. Nucleotide sequence of cDNA of the Tobacco mosaic virus RNA isolated in Korea. Nucleic Acids Res. 20:5474.

26. Kooyman, P., and Thompson, G. T. 1990. Characterization of tobamoviruses isolated from tomatoes in South Africa. Phytophylatica 22:265-267.

27. Laemmli, U. K. 1970. Cleavage of structural protein during the assembly of the head of bacteriophage T4. Nature 227:680-685
28. Lee, J. W., Kim, H. J., and Lee, E. S. 1999. The Potato in Korea. National Alpine Agriculture Experiment Station, Pyungchang, Kangwon, Korea.

29. Lee, J. Y., Jung, D. S., Chang, M. U., and Choi, J. K. 1993. Effective cloning of coat protein gene isolated from Tobacco mosaic virus pepper (TMV-P) strain. Korean J. Plant Pathol. 9:136-138.

30. Lee, J. Y., Jung, D. S., Chang, M. U., and Choi, J. K. 1995. Nucleotide sequence analysis of movement protein gene from Tobacco mosaic virus Korean pepper (TMV-KP) strain. Korean J. Plant Pathol. 11:87-90.

31. Lewandowski, D., and Dawson, W. O. 1994. Tobamoviruses, Pages 1436-1441 in: R. G. Webster and A. Granoff, ed. Encyclopedia of Virology, Vol. 3. Academic Press, San Diego.

32. Meshi, T., Takamatsu, N., Ohno, T., and Okada, Y. 1982. Molecular cloning of the complementary DNA copies of the common and cowpea strains of Tobacco mosaic virus RNA. Virology 118:64-75.

33. Nishimiya, S., Uhaki, M., Oshima, M., and Ohashi, Y. 1992. Nucleotide sequence of Tobacco mosaic virus. J. Biochem. 96:19151923

34. Palukaitis, P., Randles, J. W., Ying-Tuan, T., Liang-Yi, K., and Po, T. 1981. Taxonomy of several tobamoviruses from China as determined by molecular hybridization analysis with complementary DNA. Intervirology 16:136-141.

35. Park, E. K., Lee, C. H., Lee, Y. K., and Kim, Y. H. 1997. Biological, physico-chemical and serological characteristics of TMV strains isolated from tobacco, tomato, and pepper plants. J. Korean Soc. Tobacco Sci. 19:5-10.

36. Phatak, H. C., and Verma, V. S. 1967. A strain of tobacco mosaic from potato. Phytopathol. Z. 59:141-146.

37. Salazar, L. F. 1996. Potato Viruses and Their Control. International Potato Center (CIP), Lima, Peru.

38. Sambrook, J., Fritsch, E. F., and Maniatis, T. 1989. Molecular Cloning: A Laboratory Manual, 2nd ed. Cold Spring Harbor Laboratory, Cold Spring Harbor, NY. pp. 5.73-5.75.

39. Shintaku, M. H., Carter, S. A., Bao, Y., and Nelson, R. S. 1996. Mapping nucleotides in the $126-\mathrm{kDa}$ protein gene that control the differential symptoms induced by two strains of Tobacco mosaic virus. Virology 221:218-225.

40. Smith, K. M. 1972. A Textbook of Plant Virus Diseases. 3rd ed. Academic Press, New York.

41. Takeshi, O., Midori, A., Yuji, Y., Hiraku, S., Shuntaro, L., Tetsuo, M., and Yoshimi, O. 1984. Nucleotide sequence of the Tobacco mosaic virus (Tomato strain) genome and comparision with the common strain genome. J. Biochem. 96:1915-1923.

42. Talianski, M. E., and Garcia-Arenal, F. 1995. Role of cucumovirus capsid protein in longdistance movement within the infected plant. J. Virol. 69:916-922.

43. van Regenmortel, M. H. V. 1986. Tobacco mosaic virus. Antigenic structure. In: The Plant Viruses, Vol. 2. M. H. V. van Regenmortel and H. Fraenkel-Conrat, ed. Plenum Press, New York.

44. Wetter, C. 1984. Serological identification of four tobamoviruses infecting pepper. Plant Dis. 68:597-599.

45. Zaitlin, M., and Israel, H. W. 1975, Tobacco mosaic virus (type strain). CMI/AAB Description of Plant Viruses No. 151. 